\title{
POVEZANOST DEPRESIJE SA MENTALNIM SPOSOBNOSTIMA I SOCIO - EKONOMSKIM STATUSOM POJEDINCA
}

\section{Sažetak}

Depresija je bolest savremenog drustva. Ona ima biološku podlogu, a ogleda se u dominantnom sniženom raspoloženju. Depresija dovodi i do smetnji u pamíenju, på̌nji, koncentraciji, ozbiljnim tjelesnim promjenama kao i promjenama u ponašanju ličnosti.

Sama etiologija može biti potaknuta rąličitim psibološkim i društvenim stresovima (npr. rat, prirodne katastrofe, raqvod, gubitak bliske osobe, saobraćajni udes $i$ slično).

Predmet istraživanja ovog rada jeste ispitivanje povezanosti nivoa depresivnosti $i$ mentalnih sposobnosti. Naša polazna hipoteza je da će se depresija češce i intenzivnije javljati kod osoba oskudnib mentalnih sposobnosti $i$ u osoba slabijeg socio-ekonomskog statusa i narušene porodicne atmosfere što je istraživanje i poturdilo.

Ključne riječi: depresija, mentalne sposobnosti, socio-ekonomski status, stres, trauma.

\section{Uvod}

Depresija ili bolest našeg vremena, kako je još nazivaju, predstavlja veliki izazov za svakog liječnika, kako u primarnoj zdravstvenoj zaštiti tako i za svakog porodičnog ljekara. Kada govorimo o depresiji, među laicima ona označava privremeno razdoblje sniženog osnovnog raspoloženja koje nastupi nakon loše provedenog dana ili jednostavno neraspoloženje. Zapravo, riječ je o ozbiljnoj bolesti koja dovodi do smetnji u pamćenju, pažnji, koncentraciji, ozbiljnijim tjelesnim promjenama, kao i promjenama u ponašanju ličnosti. Depresija je bolest koja ima biološku podlogu, tj. može biti potaknuta različitim psihološkim i društvenim stresovima (rat, prirodne katastrofe, razvod, gubitak bliske osobe, saobraćajni udes...). Pri dijagnosticiranju, ranom prepoznavanju i upućivanju bolesnika na pravovremeno liječenje te preventivnom

${ }^{1}$ Univerzitet u Zenici, profesor na Pedagoškom fakultetu u Zenici.

2 JU Dom zdravlja „Izudin Mulabećirović-Izo“ Tešanj, Centar za mentalno zdravlje 
djelovanju, ne možemo zanemariti ulogu psihologa, socijalnog radnika, medicinskog radnika, pedagoga, prosvjetnog radnika i vjerskog službenika. Zajedničko traženje mogućih uzroka njihovog straha, nesanice, smanjenja potencije, te patnje osoba koje se bore sa raznim psihosomatskim oboljenjima, često navodi na postavljanje pitanja očuvanja „zdravog razuma“, odnosno preventivnog djelovanja u svrhu očuvanja mentalnog zdravlja istih. Masovna traumatizacija za vrijeme rata u Bosni i Hercegovini dovela je do naglog porasta različitih psihijatrijskih poremećaja, osobito depresije. Činjenica je da živimo i radimo u zemlji koja je u tranziciji, svakodnevno je sve veći broj nezaposlenih, osoba koje posežu za alkoholom, narkotičkim sredstvima u želji da zaborave probleme, tegobe, traumatična iskustva. Zbog svega toga jako je važno blagovremeno prepoznavanje depresije ili depresivnog poremećaja radi terapijskog djelovanja, jer 40\% - 60\% depresivnih bolesnika povoljno reaguje već na prvo liječenje.

Depresija (lat. deprimere - potištenost, utučenost, klonulost, tupost, bezvoljnost) predstavlja psihijatrijski poremećaj patološki sniženog raspoloženja. Može se javiti kao simptom ili sindrom u okviru različitih psihijatrijskih poremećaja, ili kao samostalan entitet.

U pedagoškoj enciklopediji depresija (depression) predstavlja intenzivno neraspoloženje trajnijeg karaktera. Kao mentalno oboljenje, predstavlja veoma heterogen skup pojava vezanih uz prolazno ili trajno opadanje neuropsihičke tenzije. Osnovne promjene se ogledaju u promjenama afekta koje su praćene promjenama kognitivnih procesa, socijalnih odnosa te motorike. Oboljele osobe iznose žalost, tužno raspoloženje, plačljivost, pesimizam, osjećaj krivnje, osjećaj tuge, usamljenost, odbačenost, osjećaj niže vrijednosti itd., kao i usporenje intelektualnih funkcija - mišljenje, gubitak interesovanja, slabija koncentracija.

Dakle, ukoliko je posmatramo kao simptom, depresija je patološko raspoloženje, motivaciono, kvantitativno i kvalitativno različito od normalne tuge. Kao sindrom, depresija obuhvata razne kombinacije psihičkih, psihomotornih i somatskih simptoma koji se ispoljavaju različitim intenzitetom - od blagih do psihotičnih oblika. 


\section{Metodologija istraživanja}

Uzorak istraživanja čine pacijenti Centra za mentalno zdravlje u Tešnju kod kojih je dijagnosticiran depresivni poremećaj. Ukupan broj ispitanika jeste 110. Ispitanici se razlikuju po spolu, starosti, tj. starosnoj dobi, nivou obrazovanja i socijalno-ekonomskom aspektu. Najmlađi ispitanik ima 16 godina,a najstariji ispitanik 63 godine.

- Stručna sprema ispitanika

Od ukupno 110 ispitanika, njih 8 ili 7.27\% je nepismeno. Osnovno obrazovanje stekla su 22 ispitanika, tj. $20 \%$ od ukupnog broja ispitanih. Sa srednjim obrazovanjem ih je 57 ili 51, 82\%. Višu školsku spremu, od ukupno 110 ispitanih, ima 5 ispitanika, što je u odnosu na ukupan broj ispitanih 4.55\%. Sa visokoškolskom spremom ukupno ih 18 u odnosu na 110 ispitanika u cijelom istraživanju, što je, izraženo u postocima, $16.36 \%$.

- Bračni status ispitanika

U našem istraživanju, od ukupno 110 ispitanika, njih 35 je slobodnih (31.82\%), nisu u bračnoj niti u emocionalnoj vezi. Najveći broj ispitanih, ukupno 58 , je u bračnoj zajednici $(52.73 \%)$. Samo 3 ispitanika, od ukupnog broja ispitanih, su udovac ili udovica (2.73\%). Njih 14 je razvedeno $(12.73 \%)$.

- Zaposlenost ispitanika

$\mathrm{U}$ našem istraživanju od ukupno $\mathrm{N}=110$ ispitanika, njih 52 je zaposleno, ili 47, 27\% u odnosu na 52, 73\% ili 58 ispitanih koji su nezaposleni.

- Domicilnost ispitanika

Od ukupno $\mathrm{N}=110$ ispitanika koji su sudjelovali u istraživanju, njih 87 ili $79.09 \%$ pripada starosjedilačkoj populaciji, u odnosu na doseljeničku populaciju tj. izbjeglice. Prognanih na područje općine Tešanj u našem istraživanju je 20.91\% ili 23 ispitanika od ukupno 110.

- Mjesto stanovanja

Najveći broj ispitanika u našem istraživanju je pripadao gradskoj naseljenoj zoni (njih 46 od ukupno $\mathrm{N}=110$ ispitanika, ili, izraženo u postocima, $41.82 \%)$. U prigradskom naselju ih je, od ukupnog broja 
ispitanika, bilo 30, tj. 27.27\%. I sa prebivalištem u seoskoj, ruralnoj sredini, od ukupnog broja ispitanih njih 34 ili 30.91\%.

- Socijalni status ispitanika

U jako lošim socijalnim uvjetima stanovanja (bez struje, bez vode, u uslovima življenja više članova porodice u jednoj zajedničkoj prostoriji...), od ukupno $\mathrm{N}=110$ ispitanika, njih je 3 (2.73\%). Loši uslovi stanovanja koji podrazumijevanju da kućanstvo ima priključak vode, struje, jednu zajedničku prostoriju, TV-prijemnik, grijanje na ogrjev itd., od ukupnog broja ispitanih, u takvim uvjetima živi njih 29 (26.36\%). Gotovo svako prigradsko, gradsko i ruralno kućanstvo ima priključak struje, vode, telefona i grijanje. Naveli smo kategoriju prosječnog socijalnog statusa. Navedene kriterije prosječnog socijalnog statusa u našem istraživanju ispunjavaju 44 ispitanika (40\%). Zadovoljavajući uvjeti stanovanja koji podrazumijevaju (pored telefonskog priključka, grijanja, više TV-prijemnika i Internet konekcije) i više stambenog prostora za život, u našem istraživanju od ukupnog broja ispitanika, zadovoljava njih 34 ili $30.91 \%$ od ukupnog broja ispitanih.

- Ekonomski status ispitanika

U našem istraživanju imali smo kategoriju u kojoj su ispitanici čija su mjesečna primanja manja od 400,00 KM. Njih je u našem istraživanju 18 (16.36\%), od ukupno $\mathrm{N}=110$ ispitanika koji su sudjelovali u istraživanju. U kategoriji ispitanika kod kojih su mjesečni prihodi između 400,00 - 800,00 KM, ukupno ih je 36, odnosno 32.73\%. Treća kategorija ispitanika u kojoj su ispitanici kojima mjesečni prihodi iznose preko $800,00 \mathrm{KM}$, u istraživanju ih je bilo $46 \mathrm{u}$ odnosu na ukupan broj ispitanika, što je izraženo u postocima $41,82 \%$. U posljednjoj, četvrtoj kategoriji, je njih $9.09 \%$, odnosno 10 ispitanika.

\section{Instrumentariji}

- D-92 - skala depresije,

- PERDUE - neverbalni test mentalnih sposobnosti,

- Opái upitnik na osnovu kojeg dobijemo uvid o obrazovanje i socio-ekonomske uslove života ispitanika; 


\section{Rezultati istraživanja}

Nivo depresivnosti izražen u postocima u odnosu na ukupan broj ispitanika $\mathrm{N}=110$ ispitanika je slijedeći: bez znakova depresivnosti $10 \%$ ispitanika, odnosno samo 11; blaga depresivnost - 3\% ili samo 3 ispitanika od ukupnog broja koji je sudjelovao u istraživanju (110); umjerena depresivnost - ukupno 7 ispitanika ili, izraženo u postocima, $6 \%$; teška depresivnost - ukupno $81 \%$ ili njih 89 u odnosu na ukupan broj ispitanih $\mathrm{N}=110$, što je najveći broj od ispitanih u istraživanju. Samo $10 \%$ ispitanih nema znakova depresivnosti, što je još jedan od pokazatelja koliko je ozbiljna tendenca porasta oboljelih. Dakle, $81 \%$ od ispitanih ima tešku (duboku) depresivnost, što je zabrinjavajuća činjenica ako to gledamo sa stanovišta liječenja i tretmana depresije.

Pojava depresivnosti u odnosu na spol, kao jedan od zadataka u našem istraživanju, je ispitana statističkom metodom t-testa te smo dobili slijedeće vrijednosti: srednja vrijednost, tj. prosječan rezultat koji ostvaruju ispitanici $\mathrm{M}=2,44 ; \mathrm{SD}=1,05$, a ispitanice $\mathrm{M}=2,71 ; \mathrm{SD}=$ 0.82 , te smo dobili da je konačan $t=-1,49$; nivo značajnosti 0,138 , što se na nivou rizika od $5 \%$ nije pokazalo kao statistički značajna razlika.

Ako posmatramo depresiju u odnosu na zaposlenost ispitanika, dobili smo slijedeće vrijednosti: od ukupno 110 ispitanika kojih je sudjelovalo u istraživanju, zaposlena su 52 ispitanika, srednja vrijednost depresivnosti je $\mathrm{M}=2,33, \mathrm{SD}=1,13$, u odnosu na nezaposlene ispitanike kojih je ukupno 58 , gdje smo dobili da je $\mathrm{M}=2,81, \mathrm{SD}=0,69$. Tako smo primjenom t-testa, dobili vrijednost $t=-2,74, \mathrm{p}=0,007$, što na nivou rizika od 5\% možemo tvrditi da varijabla zaposlenost pokazuje statistički značajnu razliku u odnosu na nivo depresivnosti, i to tako da nezaposleni ispitanici u većoj mjeri pokazuju veći nivo depresivnosti u odnosu na zaposlene ispitanike.

Depresija u odnosu na starosnu dob - Prosječna starosna dob ispitanika u našem istraživanju je 37, 5 godina. Najmlađi ispitanik je imao 16 godina, a najstariji 63 godine. Kao što možemo vidjeti u tabeli broj 4, gdje je opisana deskriptivna statistika, imamo ispitanike ispod 37,5 godina starosti, njih je 53 od ukupnog broja ispitanika $(\mathrm{N}=110)$. Srednja vrijednost za iste je $\mathrm{M}=2,81, \mathrm{SD}=0,59$. Ispitanici iznad 37, 5 godina, kojih je u našem istraživanju bilo 57 , gdje je srednja vrijednost depresivnosti iznosila $\mathrm{M}=2,36, \mathrm{SD}=1,15$. Statističkom obradom, $\mathrm{t}-$ testom, smo dobili da je $\mathrm{t}=2,49$, gdje je $\mathrm{p}=0,014$. Tako možemo zaključiti da stariji ispitanici imaju veći nivo depresivnosti, što su 
potvrdila i druga istraživanja koja su se bavila ispitivanjima depresije i starosne dobi. Tako se došlo do zaključka da se depresija najčešće javlja u dobi između tridesete i pedesete godine života. Broj depresivnih pacijenata veći u poznim godinama života.

Kada govorimo o domicilnosti, od ukupno 110 ispitanika, njih 87 je starosjedilaca, tj. i ranije, prije ratnih dešavanja, su živjeli na području općine Tešanj. Srednja vrijednost nivoa depresije za tu kategoriju iznosi $\mathrm{M}=2,60 ; \mathrm{SD}=0,92$; u odnosu na njih 23 koji su svrstani u kategoriju doseljeničke populacije, kod kojih srednja vrijednost iznosi $\mathrm{M}=2,48$; $\mathrm{SD}=1,08$. Statističkom obradom, tj. primjenom t-testa smo dobili da je $\mathrm{t}$ $=0,59, \mathrm{p}=0,56$, što u statističkom smislu možemo tumačiti da nema značajne razlike u pojavi depresije kod osoba koje su iz starosjedilačke populacije u odnosu na lica koja su doseljenici (izbjegli i protjerani za vrijeme rata ).

Za testiranje pojave depresije u odnosu na stručnu spremu ispitanika, koristili smo jednosmjernu analizu varijance i dobili smo slijedeće vrijednosti: depresija u odnosu na stručnu spremu $\mathrm{F}(4,105)=2,603$, za sig. 0,040, iz čega možemo zaključiti da je stručna sprema samo djelomično povezana sa pojavom depresije i to za ispitanike sa VSS koji pokazuju statistički značajno manji nivo depresivnosti u odnosu na one koji imaju samo osnovnoškolsko obrazovanje. Naše istraživanje je samo djelomično potvrdilo pretpostavku da će osobe nižeg obrazovanja biti depresivnije u odnosu na osobe sa višim stupnjem obrazovanja.

$\mathrm{U}$ jednom od zadataka u našem provedenom istraživanju potrebno je bilo ispitati odnos depresije $i$ bračnog statusa. Na našem uzorku od 110 ispitanika smo dobili da je F $(3,16)=0,404$, sig $=0,750$, iz čega možemo zaključiti da u našem istraživanju veza između depresije i bračnog statusa statistički nije značajna.

Dakle, u našem istraživanju nismo potvrdili tezu drugih istraživanja u kojima se pokazalo da su osobe koje su u bračnoj zajednici više depresivnije u odnosu na druge.

Ako posmatramo depresiju u odnosu na mjesto stanovanja, riječ je o slijedećim kategorijama: gradsko naselje $(\mathrm{N}=46)$, prigradsko naselje $(\mathrm{N}$ = 30) i seoska sredina $(\mathrm{N}=34)$, i tu smo dobili slijedeće rezultate: $\mathrm{F}$ $(2,107)=0,174 ;$ sig $=0,840$. To nas navodi na zaključak da smo primjenom statističke metode analize varijance dobili da nivo depresije 
ne ovisi o mjestu stanovanja ispitanika, tj. ne možemo izvesti zaključak da je depresija uvjetovana mjestom stanovanja.

Mnoga su se istraživanja, kao što smo već naveli, bavila istraživanjem odnosa socijalnog statusa $i$ pojave depresije, pa smo tako i mi u našem istraživanju ispitali istu pojavu te je podijelili u četiri kategorije, koje smo opisali ranije. Statističkom metodom analize varijance, za ispitivanje odnosa depresije i socijalnog statusa smo dobili slijedeće vrijednosti: $F(3,106)=1,205$; sig $=0,312$, iz čega možemo izvesti zaključak da se u našem istraživanju, vjerovatno zbog malog reprezentativnog uzorka, socijalni status (kao jedan od razloga pojave depresivnosti) nije pokazao statistički značajnim faktorom u nastanku navedenog psihičkog poremećaja - depresije.

Ekonomski status ispitanika, kao i socijalni status, ima veliki značaj u pojavi depresije. U našem smo istraživanju, vodeći se nekim općim podacima dobivenim iz općinskih institucija, naveli četiri kategorije ispitanika. Njihov ekonomski status predočen je na osnovu mjesečnih prihoda. Tako smo, posmatrajući depresiju u odnosu na ekonomski status ispitanika, dobili slijedeće vrijednosti $F(3,106)=3,353$; sig. 0,022, što je pokazalo da je ta razlika statistički značajna. $\mathrm{Na}$ osnovu toga možemo reći da su ispitanici koji su imali veća financijska mjesečna primanja, tj. bolji ekonomski status, pokazivali niži nivo depresivnosti. Ispitanici koji su bez mjesečnih prihoda ili imaju veoma niska mjesečna primanja (do 400,00 KM), imaju znatno viši nivo depresije.

Ispitujuci povezanost mentalnih sposobnosti $i$ depresije u našem istraživanju, dobili smo rezultate koji pokazuju da su depresija i nivo mentalnih sposobnosti povezani. Tu povezanost smo ispitali statističkom obradom rezultata, korelacijom, Spermanovim koeficijentom korelacije. Pokazalo se da je $\mathrm{r}=-0,279$, iz čega možemo zaključiti, na nivou rizika od $1 \%$, da postoji statistički značajna povezanost između depresije i mentalnih sposobnosti $\mathrm{i}$ to na način da ispitanici sa većim nivoom mentalnih sposobnosti imaju manji nivo depresivnosti.

\section{Zaključci istraživanja}

1. Većina ispitanika ima depresivni poremećaj. Najviše je izražena duboka depresivnost u odnosu na umjerenu i blažu depresiju;

2. Nivo depresivnosti je povezan sa mentalnim sposobnostima, $i$ to na način da ispitanici sa većim skorom na testu mentalnih sposobnosti 
imaju blažu depresivnost ili je gotovo i nemaju u odnosu na druge ispitanike koji postižu niži skor na testu mentalnih sposobnosti i kod kojih je depresivnost više izražena;

3. Muškarci i žene se međusobno ne razlikuju u nivou depresivnosti, kao ni u rezultatima na testu mentalnih sposobnosti;

4. Zaposleni ispitanici pokazuju manji nivo depresivnosti u odnosu na nezaposlene ispitanike kod kojih je depresivnost češće prisutna i znatno je jačeg intenziteta;

5. Stariji ispitanici su češće depresivniji u odnosu na mlađe ispitanike;

6. Prognanički status ne uvjetuje pojavu depresivnosti, niti utječe na mentalne sposobnosti;

7. Mentalne sposobnosti se razvijaju tokom procesa obrazovanja, tako da skor na testu mentalnih sposobnosti ima tendencu porasta sa rastom nivoa obrazovanja;

8. Socijalni status ispitanika ne uvjetuje pojavu depresije, ali ispitanici sa boljim socijalnim uslovima postižu veći skor na testu mentalnih sposobnosti;

9. Ispitanici sa boljim ekonomskim statusom pokazuju niži nivo depresivnosti i postižu veći skor na testu mentalnih sposobnosti.

\section{Diskusija}

Polazna tačka našeg istraživanja je pojam depresije, depresivni poremećaj. Kao što smo to već u samom uvodu naveli, a poslije i u teorijskom razmatranju nastanka i klasifikaciji depresivnog poremećaja, depresija je u zadnje vrijeme predmet mnogih istraživanja.

Polazeći od različitih pretpostavki, ranijih istraživanja te zaključaka istih, u našem istraživanju smo postavili hipotezu koja navodi da postoji povezanost između depresije, mentalnih sposobnosti i socio-ekonomskih faktora pojedinca.

Ako posmatramo pojavu depresije u odnosu na faktore koje smo naveli kao socio-ekonomske faktore te različit nivo obrazovanja, mjesto stanovanja, bračni status i dr., dobiveni rezultati u našem istraživanju djelomično su potvrdili zaključke i rezultate ranijih istraživanja. Tako možemo reći da je zaposlenost bitan faktor u pojavi depresivnosti, jer se 
u našem istraživanju pokazalo da su zaposleni ispitanici imali statistički značajno manji nivo depresivnosti u odnosu na one koji su bez zaposlenja. Također, pokazalo se da ispitanici koji žive u boljim socijalnim uslovima i imaju bolji ekonomski standard imaju manji nivo depresivnosti u odnosu na one koji su u socijalno ugroženoj kategoriji, kao i u odnosu na one koji imaju slabiji ekonomski status. To nas dovodi do zaključka da je jedan od preventivnih faktora u borbi s depresijom omogućavanje boljih socijalnih i ekonomskih uslova života. Nažalost, u zadnje vrijeme, kada je sve više radničke snage bez zaposlenja ili sa minimalnim prihodima koji nisu dostatni ni za osnovnu potrošačku korpu, teško je preventivno djelovati samostalno kao jedinica zdravstvene zaštite. Potrebna su djelovanja sa viših instanci. Ono što je zabrinjavajuće je da su gotovo svi ispitanici koji su sudjelovali u istraživanju pokazivali znakove depresije, samo na različitom nivou, a to je svakako alarmirajući pokazatelj.

Ispitujući povezanost pojave depresije i mentalnih sposobnosti, došli smo do rezultata koji su pokazali da osobe sa većim nivoom mentalnih sposobnosti, iako imaju depresivni poremećaj, imaju nižu razinu depresivnosti u odnosu na one koji su na testu mentalnih sposobnosti postigli niži nivo rezultata. Ovu pojavu bismo mogli objasniti činjenicom da osobe koje su pokazale bolje mentalne sposobnosti imaju i bolji način razumijevanja preventivnog djelovanja na pojavu depresije, veći stepen motiviranosti, razumijevanja i zalaganja u samom procesu liječenja depresivnog poremećaja. Možemo reći da je njihov mentalni kapacitet fleksibilniji, ili da imaju „šire vidike” u smislu pružanja samopomoći ili rada na samome sebi.

Značaj i doprinos ovog rada je višestruk. Ovo je jedan od prvih radova na području općine Tešanj koji govori o pojavi depresivnog poremećaja, kao i o faktorima koji mogu doprinijeti pojavi depresije. U našem istraživanju depresivni poremećaj je posmatran kroz prizmu različitih faktora kao što su: opća naobrazba, bračni status, socijalnoekonomski status te domicilnosti ispitanika. Također, u okviru ispitivanja depresije ispitan je i odnos depresije i mentalnih sposobnosti u odnosu na gore navedene socio-ekonomske faktore, kao i anamnestičke podatke. Naravno, zaključci ovog istraživanja mogu pomoći u planiranju preventivnog djelovanja u liječenju depresije te ukazati na potrebu uključivanja najbližih u proces liječenja osobe oboljele od depresije, ali i potrebu uključivanja drugih institucija koje mogu pomoći u oporavku i kasnijoj rehabilitaciji oboljelog. 
Ovaj rad je odgovorio na neka od pitanja koja se sama nameću u istraživanju depresije i svakako otvara mogućnost daljeg istraživanja i proučavanja.

\section{Literatura:}

1. Avison, W., Gotlib, H.: Stress and Mental Health. New York and London, Plenum press, 1994.

2. Baron,R., Richardson, D.: Depression. New York and London, Plenum press, 1994.

3. Beck, Judith: Cognitive therapy: Basics and Beyond. New York, The Guilford Press, 1995.

4. Biro,Mikloš: Osnovi kliničke psihologije. Novi Sad, Univerzitet u Novom Sadu, 1999.

5. Blažević, Duška i suradnici: Medicinska psihologija. Zagreb, Jugoslovenska medicinska naklada, 1978.

6. Cerić, Ismet /prijevod/: Uputstva za dijagnostiku $i$ tretman mentalnih poremé́aja u primarnoj zaśtiti-MKB 10. Sarajevo, Svjetska zdravstvena organizacija, Ured za BiH, 2001.

7. Nietzel, M., Bernstein,D., Milich,R.: Uvod u klinickeu psihologiju. Jastrebarsko, Naklada Slap, 1997.

8. Oruč Lj., Poljskić N.: Smjernice za ljekara u primarnoj zdravstvenoj zaštiti, Jež, 2002.

9. Schwab, J., Stephenson, J.: Evaluating family Mental Health. New York and London, Plenum press, 1993.

10. Sinanović, Osman i suradnici: Dubovnost i mentalno zdravlje. Sarajevo, Svjetlost, 2002.

11. Stojiljković, S.: Psibijatrija sa medicinskom psibologijom. Beograd - Zagreb, Medicinska knjiga, 1975. 
REFIK ĆATIĆ, PhD and EMINA TURALIĆ

\title{
CORRELATION BETWEEN DEPRESSION OF MENTAL ABILLITIES AND SOCIO-ECONOMIC STATUS OF INDIVIDUALS
}

\begin{abstract}
Depression is a disease of modern society. It has a biological basis is reflected in a reduced dominant mood. Depression leads to disturbances in memory, attencion, concentration, severe physical changes and changes in personal behavior.

The etiologycan be triggerd by a variety of psychological and social stress ( eg war, natural disaster, divorce, loss of loved one, accident at work....).

The subject of this paper is to investigate the connection between levels of depression and mental abillities. Our starting hypothesis is that depression is more intense and occur in people of scarce mentaln abillity in people of lower socio-economic status and disturbed family atmosphere, what is the research and confirmed.
\end{abstract}

Key words: depression, mental abillities, socio- economic status, stress, trauma. 
الأستاذ الدكتور رفيق تشاتيتش وأمينة تور اليتش

ارتباط الاكتئاب بالقدرات العقلية والوضع الاجتماعي الاقتصيادي للفرد

\section{الخلاصية}

الاكتئاب هو مرض المجتمع المعاصر، وله أساس بيولوجي ويتجلى في المزاج

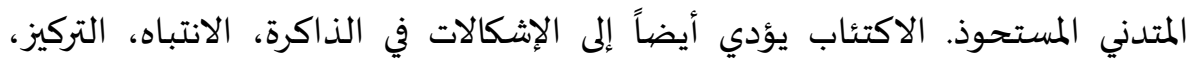

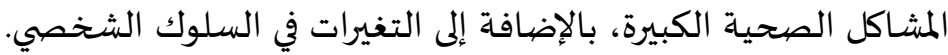

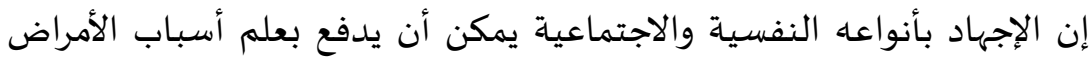

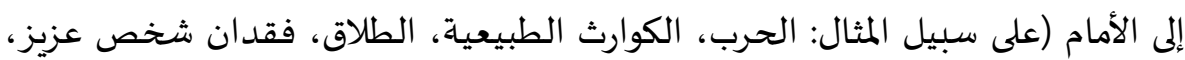

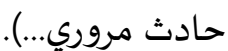

موضوع هذا البحث هو دراسة ارتباط مستوى الاكتئاب والقدرات العقلية.

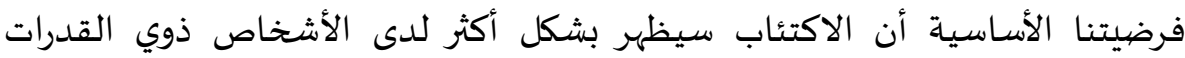

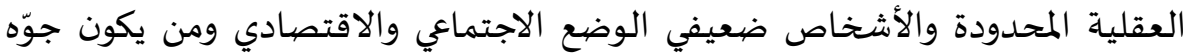
العائلي مهدم وهذا ما أكدته هذه الدراسـة. الكلمات الرئيسة: الاكتئاب، القدرات العقلية، الوضع الاجتماعي والاقتصادي، لهادي، الإجهاد، الصدمة. 